\title{
Three hulless oat varieties show economic potential as organic layer feed grain
}

\author{
Louisa R. Winkler ${ }^{1}$, Kevin M. Murphy ${ }^{1}$ and James C. Hermes ${ }^{2 *}$ \\ Department of Crop \& Soil Sciences, Washington State University, PO Box 646420, Pullman WA 99164, USA. \\ 'Department of Animal and Rangeland Sciences, Oregon State University, Withycombe Hall 112, Corvallis OR \\ 97331, USA. \\ *Corresponding author: james.hermes@oregonstate.edu
}

\begin{abstract}
Hulless oats are of interest as an alternative to corn and wheat in organic poultry diets because they offer potential to enhance agrobiodiversity and produce locally grown feeds both within and outside of corn-growing regions. Hulless oats are easily certified GM-free and have demonstrated nutritional value for poultry. A feeding study was carried out to examine: (i) the effects of substituting corn, wheat or a fraction of each with hulless oats in organic layer diets, and (ii) the importance of oat variety in feed performance. Productivity and economic implications in the context of current organic markets were explored. Experimental diets included an oat-free control, Oat + corn, Oat + wheat and Oat + corn + wheat, each of which was formulated with three hulless oat varieties, AC Gwen, Paul and Streaker. All but the control diet included oats at $200 \mathrm{~g} \mathrm{~kg}^{-1}$. Three hundred Hy-Line Brown hens were individually caged and allocated to diets in groups of 10 in a completely randomized design with three replicates per diet. Experimental diets were fed between 24 and 32 weeks of age during which time hen health, egg production and egg quality indicators were monitored. Results indicated that hulless oats had no negative effects on hen health and productivity. On the basis of current organic feed ingredient prices and an estimated cost of USD $533 \mathrm{mt}^{-1}$ for production of oats in the study region, oat containing diets were more expensive than the oat-free control. In an evaluation of revenue based on current market prices for organic eggs, the additional cost was completely offset by larger egg sizes of hens on oat containing diets. There were no major differences associated with oat variety.
\end{abstract}

Key words: poultry nutrition, hulless oats, corn, economic comparison, organic, farming systems

\section{Introduction}

In the USA, consumer demand for value added poultry products such as those from organic or pasture raised systems is expanding and is associated with consumer preference for local/regional and environmentally friendly products (Laux, 2012). Producers attempting to serve this market face difficulties sourcing appropriate feed.

Commercial poultry diets in the USA are generally reliant on corn as a carbohydrate source. Over $90 \%$ of corn grown in the USA is from genetically modified (GM) varieties (Fernandez-Cornejo et al., 2014). Seed or forage grown from such varieties is explicitly forbidden as feedstuffs in organic production, and beyond the organic market there is also substantial demand for GM-free foods (Heneghan, 2015). Not only is non-GM corn planted on a small proportion of US cropland, but contamination by wind-borne GM pollen or commingling in the supply chain also can prevent it from being sold as organic or GM-free, further limiting availability of non-GM corn (Greene et al., 2016). In recent years, US demand for organic feed corn has surpassed domestic production capacity and the shortfall has been made up by imports, primarily from Turkey, Romania and Argentina (Bjerga, 2015; Global Agricultural Trade System, 2016). US Department of Agriculture data show that imports represented $18.8 \%$ of the total value of the US organic corn supply in 2014 and that this figure is increasing year on year (National Agricultural Statistics Service, 2015; Global Agricultural Trade System, 2016). Although the availability of imports has helped improve the supply situation in recent years, a large price differential continues to exist between organic and nonorganic feed corn. The 2011-2013 3-yr average price of organic corn in the USA was USD492 $\mathrm{mt}^{-1}$ (Economic Research Service, 2014), compared with USD246 $\mathrm{mt}^{-1}$ for non-organic corn (National Agricultural Statistics Service, 2016a). 
The dominance of corn as a feed grain in the USA and the scale and methods of its cultivation have given rise to concerns about its impact on agricultural biodiversity and the natural environment (Liebman et al., 2013; Aguilar et al., 2015). At the same time, there are many regions of the USA which lack appropriate conditions for the economic production of corn for grain (Shaw, 1988): for example, the coastal Pacific Northwest lacks sufficient heat units, and the inland Pacific Northwest lacks sufficient water during the summer. In such regions, reliance on corn in poultry feed formulations represents an obstacle to the development of locally grown feed sources, which could be attractive to consumers of value added poultry products.

Wheat is also used as a carbohydrate source in poultry feeds. Wheat is the fourth most widely grown crop category in the USA following corn, soybeans and forage (National Agricultural Statistics Service, 2014). Expansion of wheat production to replace corn as a feed grain may have limited potential to enhance agricultural biodiversity at the national level, although it may offer benefits at the regional level. Like organic corn, organic wheat from domestic sources is generally in short supply. While not as expensive as organic corn, it can be a costly feed ingredient: according to USDA data, the 3-yr average organic feed wheat price for 2011-2013 was USD415 $\mathrm{mt}^{-1}$ compared with USD493 for organic corn (Economic Research Service, 2014), and USD268 for non-organic wheat during approximately the same period (Economic Research Service, 2016).

Incentives therefore exist to develop alternatives to corn and wheat in organic and/or value added poultry feeds. Hulless oats (a variant of cultivated hexaploid oat Avena sativa L.; also known as naked oats) may represent one such alternative. The oat plant is generally adapted to cooler climates than corn, offering the opportunity for its production as a locally grown feed outside traditional corn-growing areas (Brouwer and Flood, 1995). Production of oats is also practiced within traditional corn-growing regions such as Iowa, Illinois, Minnesota and Wisconsin (National Agricultural Statistics Service, 2016b), where the production of organic corn is more difficult owing to widespread presence of GM pollen. Hulless oats lack the lignified lemma and palea, which reduce the energy density of hulled (husked) oats and make them unpopular as a feed for non-ruminants. Hulless oats typically show grain oil concentration, energy density and protein concentration values surpassing those of wheat and corn (Macleod, 2004). Because GM varieties of oat are not available, oats are easier to certify GM-free than corn or soy.

In vivo studies have demonstrated the feed value of hulless oats. A broiler feeding trial carried out by Maurice et al. (1985) concluded that naked oats could constitute up to $400 \mathrm{~g} \mathrm{~kg}^{-1}$ of dietary intake without adverse effects on meat quality and production. A study of laying hens demonstrated that egg yields and feed utilization were equal where hulless oats were substituted for corn and soy, though at a high proportion $\left(600 \mathrm{~g} \mathrm{~kg}^{-1}\right)$ of dietary intake, oats were associated with a 4-day delay in sexual maturity (Cave et al., 1989). Adverse effects of hulless oat in poultry diets have been associated with their high concentration of the soluble fiber $\beta$-glucan, which can impair birds' ability to metabolize the grain (Macleod et al., 2004).

Hulless oat varieties differ in terms of both agronomic characteristics (such as yield potential or lodging resistance), affecting their ease of cultivation, and chemical composition of the grain, potentially affecting their feed value. Valentine (1995) reported grain lipid values ranging from 4.3 to $11.4 \%$ and grain protein values between 13.2 and $23.6 \%$ from 11 studies using eight hulless oat varieties. Values for $\beta$-glucan content of several hulless oat varieties evaluated in two recent studies ranged between 3.4 and 6.8\% (Macleod et al., 2004; Brindzová et al., 2008). A recent UK project reported differences for in vivo metabolizable energy values of hulless oat varieties, but did not include oat variety comparisons in feeding tests of effect on meat quality (Macleod et al., 2004). Other studies of hulless oat feed value have generally used just one variety. Whether the magnitude of grain compositional differences between hulless oat varieties is sufficient to cause a commercially or economically relevant impact on their performance in terms of practical factors such as egg productivity and feed conversion efficiency remains to be confirmed. If sufficiently large differences exist, it will be necessary to explore what variety characteristics should be sought in hulless feed oats.

The present study evaluates hulless oats as a component of layer diets in comparison with current commercial alternatives with a focus on organic systems. Corn, wheat or a fraction of each are substituted with hulless oats in organic diets fed to Hy-Line Brown birds, a commercially typical laying strain, and the effects measured in terms of hen health and egg production. Three varieties of hulless oat differing in grain oil and grain protein concentration are separately evaluated in order to explore the importance of variety choice when using hulless oats in feed. In addition, we evaluate the economic impact of replacing imported organic corn or organic wheat with locally grown hulless oats. The aim of the study is to determine whether bird health and laying system economic performance can be maintained where hulless oat is used to substitute corn and/or wheat in feed.

\section{Materials and Methods}

\section{Oat production}

Spring hulless oat varieties Streaker and Paul were selected for the present study because they are the most readily available to US growers on the commercial seed market. Canadian variety AC Gwen was also included 
although it is less readily available, because it was observed in testing nurseries to have shorter plant height and better lodging resistance than Streaker and Paul (i.e., superior agronomic characteristics).

Seed of all varieties was grown at Washington State University's Northwest Washington Research and Extension Center in Mount Vernon, WA during 2015. Oats were grown under organic management practices in a field certified organic by the Washington State Department of Agriculture according to standards established in the US Department of Agriculture's National Organic Program. They were harvested at approximately $14 \%$ grain moisture and cleaned over screens and an aspirator using a Clipper AGM 224 (A.T. Ferrell Company Inc., Blufton, IN) to remove weed seed and hull particles prior to incorporation into diets.

\section{Diets}

Four diet formulations were studied, three of which included hulless oat grain at $200 \mathrm{~g} \mathrm{~kg}^{-1}$ and one of which was an oat-free control resembling a typical commercial organic feed. So that the effect of corn, wheat and oat in the diet could be independently evaluated, the oat-based diets were (i) Oat + corn; (ii) Oat + wheat; and (iii) Oat + wheat + corn. Three versions of each oat based diet were studied, each containing one of three varieties of hulless oat: (i) AC Gwen; (ii) Paul; and (iii) Streaker. There were ten experimental diets in total.

All diets contained soy meal, vitamin-mineral mix and limestone as the calcium source and were formulated to standardize percent content of crude protein, crude lipid, calcium, phosphorous and energy value and to be sufficient in the sulfuric amino acids cysteine and methionine. Owing to lack of storage capacity and the need to purchase feed ingredients in batches, a single batch of soybean seed meal was lower in protein than other batches (44 versus 46\%). This batch was used in all diets containing oat variety Gwen, and ingredients were adjusted to achieve equivalent final protein content across diets (Table 1). All feeds, including those fed to juvenile birds, were mixed at Oregon State University and fed in mash form.

\section{Grain and feed nutritional composition}

Established procedures were used to analyze crude protein (combustion, AOAC 992.15 and 990.03; AOCS Ba 4e93), crude lipids (Soxhlet extraction, AOAC 948.22), crude fiber (AOAC 962.09) and ash (AOAC 942.05) in oat, corn and wheat grain samples and $\beta$-glucan (AOAC 995.16 and AACC 32-23.01) in oat samples (AOAC, 2005; AOCS, 2013). Amino acid analysis of oat grain was carried out using high-performance liquid chromatography after acid hydrolysis (AOAC 994.12) with preoxidation by performic acid for the sulfuric amino acids (AOAC 985.28) and base hydrolysis for tryptophan
(AOAC 988.15). Calculated nutrient concentrations were based on analyzed values for oat and reference values for other ingredients (Batal et al., 2011).

\section{Birds and housing environment}

All animal care procedures were approved by Oregon State University's Institutional Animal Care and Use Committee. They were not in accordance with US organic standards, but it was felt that they would nonetheless generate high-quality data, which was applicable to organic systems. Three hundred Hy-Line Brown chicks were obtained from Wilcox Family Farms (Roy, WA) at one day old on 15th October 2015. Chicks were wing banded and weighed. They were then brooded collectively on the floor of a fan-ventilated grow-out building with the temperature set to $35^{\circ} \mathrm{C}$ at hatch and reduced by $2^{\circ} \mathrm{C}$ week $^{-1}$ thereafter until it reached $18^{\circ} \mathrm{C}$. Feed and water were provided ad libitum throughout brooding. Chicks received a 'starter' diet from hatch to four weeks and a 'grower' diet from four to 16 weeks, both of which were formulated with corn, wheat and soy.

At 16 weeks of age, birds were weighed and placed in individual cages measuring $30.5 \mathrm{~cm} \times 45.7 \mathrm{~cm}$ in a fanventilated laying house with all cages on a single level. Laying house temperature varied between 16 and $27^{\circ} \mathrm{C}$, and photoperiod was set to $14 \mathrm{~h}$ light, $10 \mathrm{~h}$ dark. From 16 to 18 weeks of age, birds were fed a corn/wheat/soy 'pre-lay' diet and from 18 to 24 weeks, the experimental control (oat-free) diet. Oat-based experimental diets were introduced at 24 weeks of age when the hens reached nearly full production. Birds were randomly allocated as groups of ten consecutive cages to test diets such that one row of ten birds with a shared feeding trough constituted one replicate of one treatment. There were three replicates per treatment. Throughout the experiment, birds had ad libitum access to feed and water.

\section{Data collection}

Egg production by each bird was recorded daily throughout the experiment. At weeks 1, 3, 5, 7 and 9, one egg per bird was weighed and a representative sample of four eggs per replicate group (three in week 1) were evaluated for shell thickness (shell + membranes) using an Ames Pocket Thickness Measure (B. C. Ames Inc., Framingham, MA), yolk color using a Roche color fan, albumen height using an Ames Egg Quality Micrometer, and the presence of blood or meat spots in the egg. Haugh Units, a measure of egg protein quality and freshness, were calculated according to the method of Eisen et al. (1962). Hens were weighed at 0,4 and 8 weeks after the introduction of the experimental diets (i.e., at 24, 28 and 32 weeks of age). Feed consumption per group of ten hens was estimated by recording the weight of feed added to troughs at weeks 0 and 4 and the weight of feed remaining at weeks 4 and 8 of the 
Table 1. Formulation and calculated nutritional composition of experimental diets.

\begin{tabular}{|c|c|c|c|c|c|c|c|c|c|c|c|}
\hline & \multirow{2}{*}{$\begin{array}{c}\text { Control } \\
-\end{array}$} & \multicolumn{3}{|c|}{ Oat + corn + wheat } & \multicolumn{3}{|c|}{ Oat + corn } & \multicolumn{3}{|c|}{ Oat + wheat } & \\
\hline & & Gwen & Paul & Streaker & Gwen & Paul & Streaker & Gwen & Paul & Streaker & \\
\hline & \multicolumn{10}{|c|}{ Ingredients $\left(\mathrm{g} \mathrm{kg}^{-1}\right)$} & \\
\hline Oats & - & 200 & 200 & 200 & 200 & 200 & 200 & 200 & 200 & 200 & \\
\hline Corn grain (yellow) & 450 & 290 & 310 & 305 & 460 & 495 & 490 & - & - & - & \\
\hline Wheat grain (soft white) & 233 & 200 & 200 & 200 & - & - & - & 505 & 535 & 528 & \\
\hline Soy meal & 193 & 185 & 165 & 170 & 215 & 190 & 195 & 150 & 120 & 128 & \\
\hline Vitamin/mineral premix & 3.0 & 30 & 30 & 30 & 30 & 30 & 30 & 30 & 30 & 30 & \\
\hline Limestone & 75 & 75 & 75 & 75 & 75 & 75 & 75 & 75 & 75 & 75 & \\
\hline \multirow[t]{2}{*}{ Soybean oil } & 20 & 20 & 20 & 20 & 20 & 10 & 10 & 40 & 40 & 40 & \\
\hline & \multicolumn{10}{|c|}{ Nutritional composition, calculated values } & Requirement $^{l}$ \\
\hline M.E. (kcal/g) & 2.88 & 2.89 & 2.92 & 2.91 & 2.89 & 2.87 & 2.86 & 2.98 & 3.02 & 3.00 & 2.80 \\
\hline Protein $(\%)$ & 14.74 & 15.15 & 15.05 & 15.06 & 15.58 & 15.43 & 15.44 & 14.73 & 14.28 & 14.36 & 15.04 \\
\hline C18:2, linoleic acid $(\%)$ & 2.22 & 2.29 & 2.50 & 2.38 & 2.55 & 2.29 & 2.17 & 2.83 & 3.02 & 2.90 & 0.88 \\
\hline $\mathrm{Ca}(\%)$ & 3.36 & 3.37 & 3.37 & 3.37 & 3.37 & 3.36 & 3.37 & 3.37 & 3.37 & 3.37 & 3.72 \\
\hline Total P $(\%)$ & 0.59 & 0.59 & 0.58 & 0.59 & 0.59 & 0.58 & 0.58 & 0.60 & 0.59 & 0.59 & - \\
\hline Available P (\%) & 0.37 & 0.38 & 0.38 & 0.38 & 0.38 & 0.38 & 0.38 & 0.38 & 0.38 & 0.38 & 0.41 \\
\hline $\mathrm{Ca}: \mathrm{P}$ & 8.98 & 8.89 & 8.93 & 8.92 & 8.91 & 8.93 & 8.93 & 8.89 & 8.94 & 8.93 & 9.07 \\
\hline $\mathrm{Cl}(\%)$ & 0.22 & 0.23 & 0.23 & 0.23 & 0.23 & 0.23 & 0.23 & 0.24 & 0.24 & 0.24 & 0.16 \\
\hline $\mathrm{Na}(\%)$ & 0.15 & 0.16 & 0.16 & 0.16 & 0.15 & 0.15 & 0.15 & 0.17 & 0.17 & 0.17 & 0.16 \\
\hline Lysine $(\%)$ & 0.70 & 0.74 & 0.70 & 0.71 & 0.81 & 0.75 & 0.76 & 0.67 & 0.61 & 0.62 & 0.80 \\
\hline Methionine $(\%)$ & 0.34 & 0.34 & 0.33 & 0.33 & 0.37 & 0.35 & 0.35 & 0.31 & 0.29 & 0.29 & 0.39 \\
\hline Methionine + Cysteine $(\%)$ & 0.59 & 0.65 & 0.62 & 0.62 & 0.68 & 0.65 & 0.65 & 0.60 & 0.56 & 0.57 & 0.71 \\
\hline Threonine $(\%)$ & 0.46 & 0.47 & 0.55 & 0.53 & 0.53 & 0.60 & 0.57 & 0.57 & 0.49 & 0.46 & 0.61 \\
\hline Arginine $(\%)$ & 0.85 & 0.70 & 1.02 & 0.99 & 0.98 & 1.11 & 1.07 & 1.06 & 0.91 & 0.85 & 0.82 \\
\hline Isoleucine $(\%)$ & 0.65 & 0.65 & 0.74 & 0.71 & 0.71 & 0.77 & 0.74 & 0.74 & 0.70 & 0.65 & 0.62 \\
\hline Valine $(\%)$ & 0.71 & 0.70 & 0.81 & 0.79 & 0.78 & 0.86 & 0.83 & 0.83 & 0.75 & 0.71 & 0.71 \\
\hline
\end{tabular}

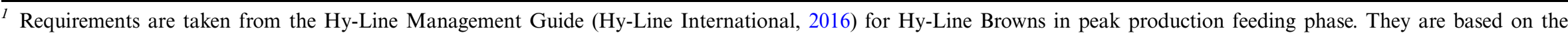
maximum listed hen.day consumption of $113 \mathrm{~g}$, which is less than average consumption in the present study. Amino acid requirements are given as total rather than digestible amino acids whose amounts are calculated for corn- and soy-based diets and therefore may not be as accurate for oat- and wheat-based diets. 
experimental treatment period. The denominator for calculating feed conversion efficiency was derived by taking the replicate-average daily egg production rate per hen in weeks $0-4$ and $5-8$, respectively, and multiplying it by that replicate's average egg weight.

\section{Economic analysis}

Economic performance of systems was estimated from egg data generated at weeks $1,3,5$ and 7 of the experimental treatment period, but in order to minimize the influence of random variability, data were aggregated to generate just two economic estimates, one for performance during weeks 1-4 and the second for performance during weeks 5-8.

At each collection date, each bird's egg was allocated by its weight to a size class according to Washington State Government Standards (Washington State Legislature, 2016). A Jumbo egg was taken to be any egg weighing $>68.4 \mathrm{~g}$, Extra Large 61.3-68.3, Large 54.2-61.2 g, Medium 47.2-54.1 g, Small 40.1-47.1 g and Peewee any egg weighing $<40.0 \mathrm{~g}$. Values used for price per egg were set with reference to organic egg national average market prices for Monday, June 27, 2016 (Agricultural Marketing Service, 2016a), taking the median of the published range for Large eggs as the reference value. Because the organic egg report does not provide prices for all size classes of egg, prices for Jumbo, Extra Large and Medium eggs were estimated using the organic egg reference value and the price differential between egg size classes of non-organic eggs published on June 29, 2016 (Agricultural Marketing Service, 2016b). The prices used in USD were: Jumbo, 0.278; Extra Large, 0.259; Medium, 0.110. None of the eggs produced in the present study was graded Small, and Peewee eggs were assumed to have no market value. The average daily egg production of each hen for each time period (weeks $0-2,2-4,4-6,6-8$ ) was multiplied by the price of the egg it laid to generate a daily revenue value for that hen at that collection date. From these values, replicate means were calculated for each 4-week interval of the economic analysis.

Feed ingredient prices used in the economic analysis are presented in Table 2. Corn, soybean seed meal and soybean oil prices were taken from organic feed ingredient market prices published by the US Department of Agriculture (Dewey, 2016). To control for the high volatility of feed markets, an average of Quarter 2 prices in 2015 and 2016 was used, except for wheat grain, where only 2015 data were published. Since the present study was conducted in the coastal Pacific Northwest, the price displayed for hulless oats in Table 2 represents cost of spring oat grain production in the Willamette Valley area of northwest Oregon as estimated in an enterprise budget published by Oregon State University Extension (Eleveld et al., 2010). The climate and economic conditions of this area were considered to be broadly
Table 2. Prices of feed ingredients used in an economic analysis of egg production from hens in a feeding trial of hulless oats in combination with corn and/or wheat.

\begin{tabular}{lc}
\hline Ingredient & ${\text { Price, } \mathbf{U S D} / \mathbf{m t}^{\mathbf{I}}}^{\mathbf{1}}$ \\
\hline Feed corn, grain & 396.39 \\
Feed wheat, grain & 437.80 \\
Hulless oats & 533.00 \\
Soybean seed meal & 1165.49 \\
Soybean oil & 781.00 \\
Fertrell Poultry Nutri Balancer & 3014.00 \\
Limestone & 220.00 \\
\hline
\end{tabular}

$I$ Prices are based on data from various sources, see Materials
and Methods for details.

representative of the greater study region. Most importantly for a conservative approach, we consider it highly unlikely that the enterprise budget underestimates the cost of producing oat grain elsewhere in the coastal Pacific Northwest. The price estimate was corrected upwards for inflation between the time of its publication (2010) and the time of writing (2016) using the consumer price index. Values for Fertrell Poultry Nutri Balancer and limestone represent the price at which they were purchased for the present study, since they were purchased from major suppliers of the organic poultry industry in this region.

\section{Statistical analysis}

The experimental design was completely randomized, with group (ten hens) as the experimental unit on which repeated measures were taken over time. There were three groups of hens (replicates) per diet/oat combination. Data were fit by restricted maximum likelihood (REML) in a linear model with diet/oat combination, time period and their interaction as fixed effects, where error across time for each individual group of hens was modeled as correlated. For each dependent variable, models using (i) compound symmetry, (ii) unstructured (iii) autoregressive and (iv) auto-regressive heterogeneous correlation structures were compared, and the most appropriate model for reporting of results was chosen on the basis of AIC, BIC and log-likelihood scores. Model residuals were examined to verify assumptions of random-normal distribution and heteroscedasticity. Comparisons between individual factor levels were carried out using linear contrasts in the chosen model. All contrasts for a given dependent variable were pre-defined and evaluated simultaneously so that reported $P$ values are adjusted for multiple comparisons (single-step procedure, Bretz et al., 2011). To compare the effect sizes of diet category (Control; Oat + corn; Oat + wheat; Oat + corn + wheat) and oat variety (Gwen, Paul or Streaker), analysis of variance was run using 'diet', 'oat variety' and 'time period' with their interactions as predictors with error modeled as a 
Table 3. Nutrient concentrations of bulk ingredients, $\%$ dry basis $^{l}$.

\begin{tabular}{|c|c|c|c|c|c|}
\hline & \multicolumn{3}{|c|}{ Oat variety } & \multirow{2}{*}{$\begin{array}{l}\text { Corn grain, } \\
\text { yellow } \\
\text { NA }\end{array}$} & \multirow{2}{*}{$\begin{array}{l}\text { Wheat grain } \\
\text { soft } \\
\text { NA }\end{array}$} \\
\hline & Gwen & Paul & Streaker & & \\
\hline Protein & 14.83 & 16.53 & 15.48 & 9.14 & 11.61 \\
\hline Crude fat & 5.92 & 8.17 & 6.31 & 3.53 & 2.06 \\
\hline $\begin{array}{l}\text { Crude } \\
\text { fiber }\end{array}$ & 4.72 & 3.22 & 4.65 & 1.63 & 2.90 \\
\hline Ash & 2.89 & 2.33 & 2.67 & 1.21 & 1.79 \\
\hline$\beta$-Glucan & 4.47 & 5.39 & 4.48 & NA & NA \\
\hline
\end{tabular}

${ }^{1}$ Values represent the mean of two subsamples.

random effect, and the proportion of total sum of squares associated with each term (both on its own and in interaction with 'time period') was taken as an approximate indication of effect size. All analyses were implemented in the $\mathrm{R}$ statistical software environment (R Development Core Team, 2008) with packages 'nlme' for the initial model fit (Pinheiro et al., 2016) and 'multcomp' for post-hoc tests (Hothorn et al., 2008).

\section{Results}

\section{Nutrient concentrations}

Chemical analysis of feed ingredients indicated that hulless oat variety Gwen was lowest and Paul was highest in concentration of both protein and fat, with a difference between the two varieties being $1.70 \%$ of grain dry matter for protein and $2.25 \%$ for fat (Table 3). Gwen was also higher in fiber than other varieties. Paul was higher in the essential amino acid lysine. These differences generally suggest that Paul may possess a better profile as a poultry feed grain, but Paul was also higher in the insoluble fiber $\beta$-glucan, which can inhibit nutrient uptake in avian digestive systems. Also, amino acid profiles of the grain differed such that despite having lower crude protein content, Gwen was nonetheless higher in the essential sulfuric amino acids, methionine + cysteine (Table 4). All oat samples were substantially higher in both protein and fat than corn and wheat samples analyzed, but were also higher in fiber.

Final diet formulations and calculated nutrient concentrations are presented in Table 1 . The Oat + wheat and Control diets showed somewhat lower protein content than other diets. Nutrient concentrations in all diets tended to be lower than required values, but feed consumption in the present study $\left(137 \mathrm{~g} \mathrm{day}^{-1}\right.$ in weeks $1-4$ and $151 \mathrm{~g} \mathrm{day}^{-1}$ in weeks 5-9) was higher than that on which the published requirements are based $(113 \mathrm{~g}$ $\left.\mathrm{day}^{-1}\right)$. Overall, it appears likely that while most nutritional requirements of birds were met by each diet, Oat + wheat and Control diets may have verged on deficiency in the essential amino acids methionine and cysteine, and the Oat + wheat diets in the essential amino acid lysine.
Table 4. Poultry-digestible amino acid content of three varieties of hulless oat grain, $\%$ dry basis.

\begin{tabular}{lccc}
\hline & \multicolumn{3}{c}{ Oat variety } \\
\cline { 2 - 4 } & Gwen & Paul & Streaker \\
\hline Methionine & 0.22 & 0.21 & 0.20 \\
Cysteine & 0.38 & 0.36 & 0.35 \\
Methionine + Cysteine & 0.60 & 0.56 & 0.55 \\
Lysine & 0.51 & 0.54 & 0.50 \\
Threonine & 0.41 & 0.45 & 0.42 \\
Arginine & 0.91 & 1.06 & 0.95 \\
Isoleucine & 0.46 & 0.55 & 0.48 \\
Leucine & 0.95 & 1.07 & 1.00 \\
Valine & 0.66 & 0.74 & 0.68 \\
Histidine & 0.29 & 0.35 & 0.31 \\
Phenylalanine & 0.64 & 0.80 & 0.72 \\
\hline
\end{tabular}

\section{Hen health and productivity}

Hen body weights tended to increase during the experiment, consistent with expectations based on their age, but decreased between weeks 5 and 8 of the experimental period for all three Oat + wheat diets (Fig. 1). Analysis showed a significant interaction between diet and time period on body weight $(P<0.05$, Table 54$)$, and contrasts showed that the difference in weight change between Oat + wheat and all other diets during the second half of the experiment was statistically significant $(P<0.01$, contrast estimate $-32 \mathrm{~g}$, see Table 6 for standard error and confidence intervals).

Egg production was close to maximum for all treatment groups throughout the duration of the experiment, the least productive group, Oat + wheat/Gwen producing at 97\% (Table 5). Analyses detected no significant effect of diet, time period or the interaction between them on daily egg production. To eliminate the influence of the initial period after test diet introduction, during which the hens were still adjusting to the experimental diets, a subset of the data from weeks 4 to 10 were extracted for analysis with the same model. No significant terms were yielded in this model either.

The whole trial average egg weight was $60.5 \mathrm{~g}$. The greatest diet/oat mean egg weight was attained with the Oat + wheat + corn/Gwen diet during week 5 of the experiment. With the exception of this and the Oat + corn/Paul diet, which also showed peak egg weight at week 5 , all diets showed peak egg weight at seven weeks. Both time period and the interaction between diet and time period were shown in the initial model to have significant effects on egg weight. Contrasts were carried out to explore the effects of oat, wheat and corn in all nine oat based diets during weeks 3-9, when hens were expected to have adjusted to the experimental diets. The six corn containing diets tended to yield heavier eggs during this period than the three corn free diets $(+1.49 \mathrm{~g})$, and the difference approached statistical significance $(P=0.09)$. 


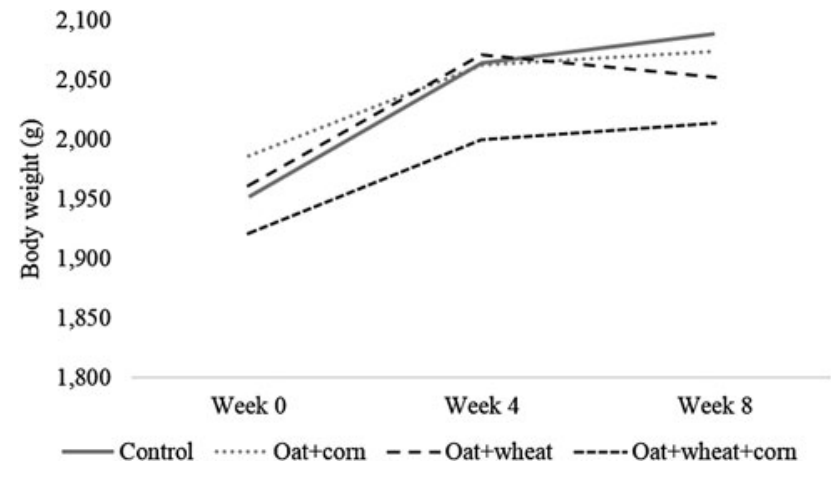

Figure 1. Hen body weights measured at 0, 4 and 8 weeks after introduction of experimental diets. Values are averaged across oat varieties and represent the mean weight in $\mathrm{g}$ of 90 birds per diet.

Wheat-containing diets tended to yield lighter eggs than the wheat-free diet $(-0.92 \mathrm{~g})$, but the difference was not significant. The Control diet was not significantly different from Oat + wheat or Oat + wheat + corn diets but tended to yield substantially lighter eggs in weeks $1-4$ and marginally lighter eggs in weeks 5-8 (Table 6).

Feed conversion efficiency ( $\mathrm{g}$ feed per g egg) was similar for most diets during both time periods, tending to be lower in Oat + wheat diets (2.3 versus $2.2 \mathrm{~g}$ for the average of all other diets). Feed conversion efficiency showed a small but significant decrease over time from $2.2 \mathrm{~g}$ in weeks $1-4$ to $2.3 \mathrm{~g}$ in weeks $5-8$ of the experiment. Oat variety accounted for a very small proportion of variance in feed conversion efficiency, relative to diet (3.2 versus $18.9 \%$, Table 7 ).

\section{Egg quality}

Higher scores on the Roche color fan indicate greater intensity of yellowness. Mean yolk color scores during weeks 3-9 of the trial were 7.1 on the control diet and 6.1-7.0 on the Oat + corn diets. They were intermediate in the Oat + corn + wheat diet and lowest in the Oat + wheat diets, providing evidence in support of their association with corn. Effects of both diet and time were highly significant $(P<0.001)$ and there was no interaction between them. While diet explained approximately $80.9 \%$ of yolk color variance, oat variety accounted for only $0.7 \%$ (Table 7 ). Therefore, diets were the focus of post-hoc comparisons. Corn-containing diets had significantly higher color scores than corn-free diets by 4 on average $(P<0.001)$, and wheat-containing diets had lower scores by 3 on average $(P<0.001$, Table 7$)$ during weeks 3-9 of the experimental period, when the birds were adjusted to the diets.

Shell thickness was significantly affected by time period but not by diet. Eggs from all diets showed similar whole trial mean shell thickness measurements of $0.38-0.40 \mathrm{~mm}$.

Whole-trial average Haugh Unit measurement was 79.7. Haugh Units showed near significant influence of diet $(P=0.066)$ and significant influence of time period $(P$ $<0.001)$, tending to fall over the course of the experiment. In contrast to other variables, sum of squares partitioning for Haugh Units suggested that oat variety accounted for more variance than did diet (5.4 versus 3.5\%, Table 7). Since neither accounted for statistically significant variation, however, this trend could not be further explored.

Whole-trial frequency of meat spots ranged between 0.077 for Oat + wheat + corn/Gwen and 0.328 for Oat + wheat/Paul, with a mean of 0.164 across all treatments. Both diet and time period had significant effects on meat spot occurrence $(P<0.01)$, but their interaction was not significant. Multiple comparisons were therefore carried out on a model which pooled time period with error. They showed that no diet/oat combination was significantly different from the control diet, though three pairwise oat based diet contrasts were significant $(\alpha=$ 0.05 , Table 6). The whole-trial average frequency of blood spot occurrence in eggs was 0.18 , with maximum by group of 1.0 and minimum of 0 . There were no differences associated with diet or time period.

\section{Economic analysis}

Cost and revenue data are displayed in Table 8. Estimated cost per $100 \mathrm{~kg}$ of experimental diets ranged between USD62.95 for the Control and 65.98 for Oat + wheat/ Gwen. Gwen diets tended to be more expensive owing to the larger quantity in their formulations of soybean seed meal or soybean oil or both. These formulations took into account both the lower protein concentration of Gwen oats and the lower protein content of the soybean seed meal available for those diets. Oat inclusion had a strong influence on diet cost since it was the second most expensive bulk ingredient after soybean seed meal. Analyses showed no significant difference between diet/ oat combinations and no significant interaction between diet and time period for gross revenue.

All diets were associated with an increase in estimated net revenue between weeks 1-4 (USD1.29) and 5-8 (USD1.40), despite reduced feed conversion efficiency. Net revenue on seven of nine oat-based diets was higher than that on the control in weeks $1-4$ of the experiment (Oat + corn/Paul and Oat + wheat + corn/Gwen being the exceptions). In weeks $5-8$, only four of nine oatbased diets earned as much as or more than the control. Nonetheless, no differences between diets or diet/oat combinations in terms of gross or net revenue were detected in statistical analyses. Oat variety accounted for a marginal proportion of variance relative to diet in sum of squares partitioning for gross and net revenue (Table 7).

\section{Discussion}

The use in organic poultry feed of hulless oat as an alternative to corn or wheat has incentives, including the potential 
Table 5. Treatment means with pooled standard error and statistical significance of treatment effects after model fit by REML ${ }^{l}$.

\begin{tabular}{|c|c|c|c|c|c|c|c|c|c|c|}
\hline & \multirow{2}{*}{$\begin{array}{c}\text { Control } \\
-\end{array}$} & \multicolumn{3}{|c|}{ Oat + corn } & \multicolumn{3}{|c|}{ Oat + wheat } & \multicolumn{3}{|c|}{ Oat + wheat + corn } \\
\hline & & Gwen & Paul & Streaker & Gwen & Paul & Streaker & Gwen & Paul & Streaker \\
\hline Hen body weight, weeks $1-9(\mathrm{~g})^{2}$ & 2035 & \multicolumn{9}{|c|}{$S E M \pm 5.9$ diet $\mathrm{ns}$ time period ${ }^{* * *}$ diet $\times$ time period $^{*}$} \\
\hline Egg production, weeks 1-9 (eggs hen.day $\left.{ }^{-1}\right)^{3}$ & 0.99 & 0.99 & 0.98 & $\begin{array}{c}0.98 \\
S E M \pm 0.002\end{array}$ & $\begin{array}{c}0.97 \\
\text { ns time }\end{array}$ & $\begin{array}{c}0.99 \\
d^{* * *}\end{array}$ & $\begin{array}{c}0.99 \\
\text { time perio }\end{array}$ & 0.98 & 0.99 & 0.99 \\
\hline Egg production, weeks 3-9 (eggs hen.day $\left.{ }^{-1}\right)^{3}$ & 0.99 & \multicolumn{9}{|c|}{$S E M \pm 0.002$ diet $\mathrm{ns}$ time period ${ }^{* * *}$ diet $\times$ time period $\mathrm{ns}$} \\
\hline Egg weight, weeks $1-9(\mathrm{~g})^{4}$ & 60.3 & 61.5 & 59.5 & $\begin{array}{c}62.2 \\
S E M \pm 0.18\end{array}$ & $\begin{array}{c}59.9 \\
\text { ns time }\end{array}$ & $\begin{array}{r}59.8 \\
o d^{* * *}\end{array}$ & $\begin{array}{c}59.2 \\
\times \text { time peric }\end{array}$ & 61.1 & 60.8 & 60.5 \\
\hline Egg weight, weeks 5-9 (g) ${ }^{4}$ & \multicolumn{10}{|c|}{$S E M \pm 0.256$ diet $\mathrm{ns}$ time period ${ }^{* * *}$ diet $\times$ time period $^{* *}$} \\
\hline Yolk color intensity (Roche scale) ${ }^{4}$ & \multicolumn{10}{|c|}{$S E M \pm 0.18$ diet $^{* * *}$ time period $^{* * *}$ diet $\times$ time period $^{* * *}$} \\
\hline Shell thickness $(\mathrm{mm})^{4}$ & 0.38 & \multicolumn{9}{|c|}{$S E M \pm 0.001$ diet $\mathrm{ns}$ time period ${ }^{* * *}$ diet $\times$ time period $\mathrm{ns}$} \\
\hline Haugh Units ${ }^{4}$ & \multicolumn{10}{|c|}{$S E M \pm 0.43$ diet $\uparrow^{\dagger}$ Time period ${ }^{* * *}$ diet $\times$ time period $\mathrm{ns}$} \\
\hline Blood spots (frequency) ${ }^{4}$ & 0.22 & \multicolumn{5}{|c|}{$S E M \pm 0.018$ diet $\mathrm{ns}$ time period ${ }^{* * *}$ diet $\times$ time period $\mathrm{ns}$} & $\begin{array}{c}0.21 \\
\text { time perio }\end{array}$ & 0.15 & 0.17 & 0.27 \\
\hline Meat spots (frequency) ${ }^{4}$ & 0.22 & \multicolumn{8}{|c|}{$S E M \pm 0.016$ diet $^{* *}$ time period $* * *$ diet $\times$ time period $\mathrm{ns}$} & 0.27 \\
\hline
\end{tabular}

${ }^{l}$ Probability value codes are $\mathrm{ns}=$ nonsignificant, $*=P \leq 0.05, * *=P \leq 0.01, * * *=P \leq 0.001$, and $\dagger=P \leq 0.10$. All data were collected from three replicates of ten hens each. 'Diet' indicates the nine combinations of diet formulation (Oat + corn, Oat + wheat, Oat + wheat + corn) and oat variety (Gwen, Paul, Streaker); 'Time period' indicates intervals at which measurements were taken (differing depending upon the variable, see below). Pooled standard error of the mean (SEM) is calculated from 150 observations.

2 Values represent the average of measurements taken at 24, 28 and 32 weeks of age (i.e., 0,4 and 8 weeks after introduction of experimental diets).

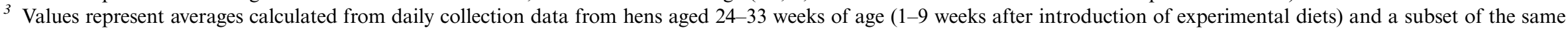
dataset from 27 to 33 weeks (3-9 weeks after introduction of test diets).

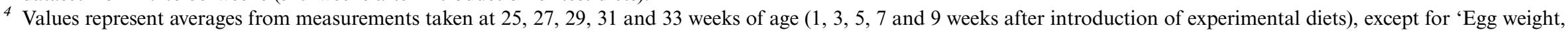
weeks 5-9' which only includes measurements taken at 29, 31 and 33 weeks. 
Table 6. Summary of planned linear contrasts to explore experimental diet effects on hen body weight, egg production and egg quality.

\begin{tabular}{|c|c|c|c|c|c|c|c|}
\hline \multirow[b]{2}{*}{ Dependent variable $^{I}$} & \multirow[b]{2}{*}{ Left side } & \multirow[b]{2}{*}{ Right side } & \multicolumn{3}{|c|}{$95 \%$ confidence interval } & \multirow[b]{2}{*}{ SE } & \multirow[b]{2}{*}{$\boldsymbol{P}^{2}$} \\
\hline & & & Lower & Est. & Upper & & \\
\hline \multirow[t]{7}{*}{ Hen body weight (kg) } & Oat + wheat diets $(n=3)$ gain: weeks $4-8$ & All other diets $(n=7)$ gain: weeks $4-8$ & -56.72 & -32.97 & -9.21 & -9.29 & $* * *$ \\
\hline & Diets with Gwen oat $(n=3)$ week 4 & Diets with Paul oat $(n=3)$ week 4 & -0.08 & -0.01 & 0.06 & 0.03 & ns \\
\hline & Diets with Paul oat $(n=3)$ week 4 & Diets with Streaker oat $(n=3)$ week 4 & -0.05 & 0.02 & 0.10 & 0.03 & ns \\
\hline & Diets with Gwen oat $(n=3)$ week 4 & Diets with Streaker oat $(n=3)$ week 4 & -0.06 & 0.01 & 0.08 & 0.03 & ns \\
\hline & Diets with Gwen oat $(n=3)$ week 8 & Diets with Paul oat $(n=3)$ week 8 & -0.09 & -0.01 & 0.06 & 0.03 & ns \\
\hline & Diets with Paul oat $(n=3)$ week 4 & Diets with Streaker oat $(n=3)$ week 8 & -0.05 & 0.02 & 0.10 & 0.03 & ns \\
\hline & Diets with Gwen oat $(n=3)$ week 8 & Diets with Streaker oat $(n=3)$ week 8 & -0.06 & 0.03 & 0.08 & 0.03 & ns \\
\hline \multirow[t]{8}{*}{ Egg weight $(g)$} & Oat-based diets with corn $(n=6)$ weeks 5-9 & Oat-based diets without corn $(n=3)$ weeks $5-9$ & -0.13 & 1.49 & 3.11 & 0.61 & $\dagger$ \\
\hline & Oat-based diets with wheat $(n=6)$ weeks $5-9$ & Oat-based diets without wheat $(n=3)$ weeks 5-9 & -2.54 & -0.92 & 0.70 & 0.61 & ns \\
\hline & Control diet $(n=1)$ week 5 & Oat + corn diets $(n=3)$ week 5 & -5.16 & -2.02 & 1.11 & 1.19 & ns \\
\hline & Control diet $(n=1)$ week 5 & Oat + wheat diets $(n=3)$ week 5 & -3.06 & 0.08 & 3.21 & 1.19 & ns \\
\hline & Control diet $(n=1)$ week 5 & Oat + wheat + corn diets $(n=3)$ week 5 & -5.10 & -1.97 & 1.17 & 1.19 & ns \\
\hline & Control diet $(n=1)$ week 9 & Oat + corn diets $(n=3)$ week 9 & -2.87 & 0.27 & 3.40 & 1.19 & ns \\
\hline & Control diet $(n=1)$ week 9 & Oat + wheat diets $(n=3)$ week 9 & -0.77 & 2.37 & 5.50 & 1.19 & ns \\
\hline & Control diet $(n=1)$ week 9 & Oat + wheat + corn diets $(n=3)$ week 9 & -2.88 & 0.26 & 3.39 & 1.19 & ns \\
\hline \multirow[t]{2}{*}{ Yolk color (Roche scale) } & Oat-based diets with corn $(n=6)$ weeks 5-9 & Oat-based diets without corn $(n=3)$ weeks 5-9 & 4.03 & 4.41 & 4.79 & 0.17 & $* * *$ \\
\hline & Oat-based diets with wheat $(n=6)$ weeks $5-9$ & Oat-based diets without wheat $(n=3)$ weeks 5-9 & -3.86 & -3.48 & -3.10 & 0.17 & $* * *$ \\
\hline \multirow[t]{4}{*}{ Meat spots (frequency) } & Oat + wheat $/$ Paul $(n=1)$ weeks $1-9$ & Oat + wheat + corn $/$ Gwen $(n=1)$ weeks $1-9$ & 0.04 & 0.25 & 0.46 & 0.07 & $* *$ \\
\hline & Oat + wheat $/$ Paul $(n=1)$ weeks $1-9$ & Oat $+\operatorname{corn} /$ Paul $(n=1)$ weeks $1-9$ & 0.02 & 0.24 & 0.46 & 0.07 & $*$ \\
\hline & Oat + wheat $/$ Paul $(n=1)$ weeks $1-9$ & $-\quad$ Oat + wheat/Gwen $(n=1)$ weeks $1-9$ & 0.00 & 0.22 & 0.44 & 0.07 & * \\
\hline & \multicolumn{2}{|c|}{ All remaining possible pairwise comparisons amongst oat/diet combinations $(n=9)$ weeks $1-9$} & \multicolumn{5}{|c|}{ All ns } \\
\hline
\end{tabular}

${ }^{I}$ Contrasts were carried out for variables where statistically significant effects of diet or diet $\times$ time period were identified in model fit by REML (Table 4).

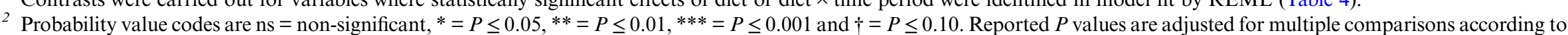
the number of contrasts carried out; see Materials and Methods for details. 
Table 7. Percent variance explained by oat variety versus diet.

\begin{tabular}{lcc}
\hline & \multicolumn{2}{c}{ \% variance explained } \\
\cline { 2 - 3 } Dependent variable $^{\mathbf{I}}$ & ${\text { Diet }(\boldsymbol{n}=\mathbf{3})^{\mathbf{3}}}$ & ${\text { Oat variety }(\boldsymbol{n}=\mathbf{3})^{\mathbf{4}}}$ \\
\hline Hen bodyweight & $\mathbf{1 5 . 8}$ & $\mathbf{1 . 3}$ \\
Egg production weeks 0-9 & 10.0 & 6.4 \\
Egg production, weeks 3-9 & 13.6 & 8.5 \\
Egg weight & $\mathbf{1 0 . 0}$ & $\mathbf{6 . 4}$ \\
Yolk color & $\mathbf{8 0 . 9}$ & $\mathbf{0 . 7}$ \\
Shell thickness & 7.9 & 6.5 \\
Haugh Units & 3.5 & 5.4 \\
Blood spots & 6.0 & 14.1 \\
Meat spots & $\mathbf{3 . 4}$ & $\mathbf{4 . 5}$ \\
Feed conversion efficiency & 18.9 & 3.2 \\
Gross revenue & 10.2 & 1.6 \\
Net revenue & 16.8 & 0.8 \\
\hline
\end{tabular}

$\bar{l}$ Estimated as proportion of total sum of squares allocated to each term in an analysis of variance using diet, oat variety, time period and their three-way interactions as predictors, with error as a random term.

2 Bold font indicates variables for which significant effects of diet or diet $\times$ time period were identified in model fit by REML (Table 4).

3 Diets were Oat + corn, Oat + wheat and Oat + wheat + corn.

4 Oat varieties were Gwen, Paul and Streaker.

to increase agricultural biodiversity, enhanced possibilities for locally grown feeds both within and outside corngrowing regions, ease of GM-free certification and the opportunity to appeal to consumer concern about these issues. At the core of producers' sustainability, however, is the biological and economic performance of their system. The present study was developed in order to establish whether hulless oats in poultry diets can sustain hen health, productivity and the economic performance of organic laying systems as effectively as wheat or corn, in the current production and market context.

\section{Oat-corn-wheat comparison}

Chemical analysis showed that oat varieties included in the present study were higher in both protein and fat than corn or wheat samples, but also higher in fiber (Table 3). Previous work has shown that $\beta$-glucan, a soluble fiber found in oat and barley grain, can reduce feed conversion efficiency and cause sticky droppings in poultry (McNab and Smithard, 1992; Józefiak et al., 2006). It was therefore of interest in the present study to monitor $\beta$-glucan concentration resulting from inclusion of hulless oats in our experimental diets. Chemical analysis showed that the oat variety with highest $\beta$-glucan concentration was Paul $(5.39 \% \mathrm{db})$. With hulless oats included in feed at $20 \mathrm{~g} \mathrm{~kg}^{-1}$ and with no other ingredients containing $\beta$ glucan, final formulations using variety Paul are estimated to have contained just $1.08 \% \beta$-glucan. Based on evidence from Welch et al. (1988) that the minimum concentration at which $\beta$-glucan shows anti-nutritional effects in poultry diets is between 2.6 and $3.4 \%$, we conclude that $\beta$-glucan is unlikely to have influenced experimental diet performance in the present study.

Reduced intensity of yolk color was observed in Oat + wheat and to a lesser extent in Oat + wheat + corn diets. This effect was expected, since neither wheat nor oats contain carotenoid pigments, whereas corn is rich in xanthophylls. Loss of yolk color arising from the substitution of corn for wheat was reported in previous work by Hsun and Maurice (1992) and Burrows et al. (1993). Consumers tend to prefer more intensely orange-colored yolks, associating them with stronger flavor and greater health-promoting properties (Hernández et al., 2005; Hernández and Blanch, 2006; Sandeski et al., 2014; Spada et al., 2016), so poultry producers substituting hulless oats for corn may need to consider supplementing other ingredients to intensify yolk coloration such as alfalfa or marigold meal (Marusich and Bauernfeind, 2012). The cost of such supplementation will depend upon the market price of the supplement chosen, the fraction of the diet at which it is incorporated and the ingredient(s) which it replaces, and should be an economic consideration in future research in this area.

While hen body weight and egg weight were equivalent on control, Oat + corn and Oat + corn + wheat diets, hens on the Oat + wheat diets lost weight during weeks 5-8 and tended to yield lighter eggs. It is not possible to conclude from our data whether these observations are explained by properties of corn or wheat or by uncontrolled variation in nutrient concentrations of the experimental diets. We were not able to achieve perfect equalization of crude protein and essential amino acids across diets, and calculated analysis suggested that Oat + wheat formulations may have been deficient in protein (Table 1). The trend toward reduced feed conversion efficiency of hens on Oat + wheat diets (Table 8) also suggests protein deficiency. Cave et al. (1989) previously reported association of lower protein diets with reduced feed conversion efficiency; and they observed no effect on hen body weight of feeding hulless oat at $300,600,782$ or $808 \mathrm{~g} \mathrm{~kg}^{-1}$ for 51 weeks.

Oats are reported to contain a higher concentration of antioxidants than other feed grains (Webster, 2011), raising the possibility that their inclusion in layer diets could improve the oxidative stability of yolk and albumen, delaying deterioration in storage and thereby offering a benefit to the consumer and a marketing advantage. Albumen viscosity is increased by the presence of antioxidants, and is easily measured by the albumen height of the broken-out egg. The Haugh Unit index adjusts the raw albumen height measurement for the size of the egg. Previous investigators have examined the influence of hulless oats on Haugh Unit values. Macleod (2004) reported a change in Haugh Unit value of +1.9 in eggs from hens fed with $250 \mathrm{~g} \mathrm{~kg}^{-1}$ and +5.0 in eggs from hens fed with $500 \mathrm{~g} \mathrm{~kg}^{-1}$ hulless oats. The 
Table 8. Components of economic analysis ${ }^{I}$.

\begin{tabular}{lccccc}
\hline Diet & Oat variety & $\begin{array}{l}\text { Feed cost, } \\
\text { USD/100 kg }\end{array}$ & $\begin{array}{l}\text { Feed conversion } \\
\text { efficiency, g per g egg }\end{array}$ & $\begin{array}{l}\text { Gross revenue per } \\
\text { ten hens per day, USD }\end{array}$ & $\begin{array}{l}\text { Net revenue per } \\
\text { ten hens per day, USD }\end{array}$ \\
\hline Control & - & 62.59 & $2.21 \pm 0.06$ & $2.16 \pm 0.1$ & $1.34 \pm 0.09$ \\
Oat + corn & Gwen & 64.63 & $2.11 \pm 0.02$ & $2.31 \pm 0.07$ & $1.46 \pm 0.07$ \\
& Paul & 63.09 & $2.21 \pm 0.05$ & $2.20 \pm 0.04$ & $1.38 \pm 0.02$ \\
& Streaker & 63.46 & $2.19 \pm 0.05$ & $2.37 \pm 0.04$ & $1.51 \pm 0.04$ \\
Oat + wheat & Gwen & 65.98 & $2.31 \pm 0.04$ & $2.18 \pm 0.07$ & $1.29 \pm 0.06$ \\
& Paul & 63.79 & $2.23 \pm 0.03$ & $2.17 \pm 0.11$ & $1.32 \pm 0.10$ \\
Oat + wheat + corn & Streaker & 64.14 & $2.30 \pm 0.05$ & $2.18 \pm 0.06$ & $1.31 \pm 0.04$ \\
& Gwen & 66.18 & $2.14 \pm 0.07$ & $2.21 \pm 0.09$ & $1.38 \pm 0.07$ \\
& Paul & 64.00 & $2.19 \pm 0.04$ & $2.26 \pm 0.07$ & $1.43 \pm 0.06$ \\
\hline
\end{tabular}

\footnotetext{
${ }^{I}$ Reported values represent mean \pm standard error based on three ten-hen replicates per treatment.
}

2 Costs reflect diets as formulated in the present study; for formulations, see Table 3.

same author reported that thiobarbituric acid reactive substances, formed as a byproduct of lipid peroxidation and inhibited by the presence of antioxidants, was lower in stored eggs from hens fed 250 or $500 \mathrm{~g} \mathrm{~kg}^{-1}$ hulless oats than from those on wheat-based diets (Macleod, 2004). In the present study, eggs from oat containing diets did not have consistently greater Haugh Unit values than eggs from the oat-free control (Table 5). The proportion of oats in our experimental formulations was lower than either of those used by Macleod (2004), suggesting that a higher proportion may be required for detectable effects. We also did not compare stored to fresh eggs, and therefore cannot exclude the possibility that oats at $200 \mathrm{~g} \mathrm{~kg}^{-1}$ may yet contribute to improved keeping qualities. This would be an interesting avenue for further research.

The general lack of treatment effects in the present study suggests that inclusion of hulless oats in layer diets is not associated with negative effects on hen health or productivity, a finding which concurs with previous work. Macleod (2004) observed no effect on feed conversion efficiency, egg production or egg weight of including oats at 250 or $500 \mathrm{~g} \mathrm{~kg}^{-1}$ in Lohmann Brown and Isa Brown laying hens for 53 weeks. Similarly, Cave et al. (1989) observed no significant effects of hulless oat inclusion on final body weight, shell characteristics or feed utilized per egg laid. They did, however, report a $4.7 \%$ improvement in feed conversion efficiency on diets containing $600 \mathrm{~g} \mathrm{~kg}^{-1}$ hulless oat $(P<0.05)$, an effect they attributed to higher crude protein in oat containing diets, which resulted from formulating for equal lysine levels. Hsun and Maurice (1992) found that they could include hulless oats at up to $66 \mathrm{~g} \mathrm{~kg}^{-1}$ of layer diets in place of all or part of the corn and all or part of the soybean meal with no adverse effects on performance.

\section{Economic analysis}

Although estimated feed costs for oat containing diets were higher than that of the control diet in the present
Table 9. Number of eggs graded Large, Extra Large or Jumbo (mean per group per treatment) ${ }^{I}$.

\begin{tabular}{lccc}
\hline Diet & Oat variety & Weeks 1-4 & Weeks 5-8 \\
\hline \multirow{2}{*}{ Control } & - & 15 & 19 \\
Oat + corn & Gwen & 19 & 19 \\
& Paul & 17 & 18 \\
Oat + wheat & Streaker & 19 & 19 \\
& Gwen & 17 & 18 \\
Oat + wheat + corn & Paul & 16 & 18 \\
& Streaker & 15 & 18 \\
& Gwen & 16 & 19 \\
& Paul & 18 & 18 \\
\hline
\end{tabular}

1 Values represent eggs per group of ten hens, averaged across three replicates; number of weeks represents weeks after introduction of experimental diets, when hens were 24 weeks of age. Eggs were weighed twice at 2-week intervals each during weeks $1-4$ and 5-8.

study, net revenues were not significantly different. This appears to have been because the oat-based diets tended to yield larger eggs than the control diet, particularly in the first half of the experiment (Table 9, Fig. 2). A similar observation was made by Cave et al. (1989), who reported a $2 \%$ increase in egg weight when corn and soybean meal was substituted for $300,600,782$ or $808 \mathrm{~g} \mathrm{~kg}^{-1}$ hulless oats. Those authors attributed the effect to increased intake of fat associated with the oats.

Recognizing that markets are constantly evolving and the assumptions on which our economic analysis is based will not hold in every case, we took what we considered to be a strongly conservative approach. The cost of oats as a feed ingredient will depend on the efficiency of their production, and we assumed efficiency to be low, reflecting the relative lack of cultivation experience with hulless oats in the study region of the coastal Pacific Northwest. Even on this basis, results suggest that hulless oats do not incur an economic sacrifice for 


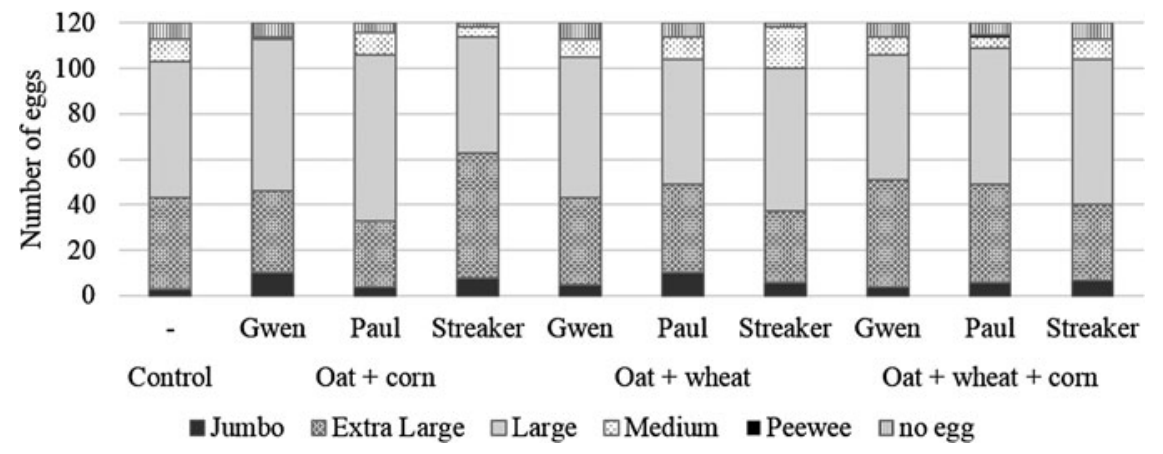

Figure 2. Size distribution of eggs produced by hens fed ten experimental diets between 24 and 32 weeks of age. Number of eggs per treatment represents a sample of four days' worth of eggs, collected respectively during weeks 3, 5, 7 and 9 of the experiment from three replicates of ten birds each per diet. Egg size grades were based on weight; see Materials and Methods for details.

organic laying systems. Efficiency gains through the use of improved oat varieties from modern plant breeding programs and the accumulation of production experience could bring down the price of oats in the region and further enhance the competitiveness of oat-based diets.

\section{Oat variety comparisons}

The three oat varieties included in the present study varied in protein, fat, crude fiber and $\beta$-glucan by $1.7,2.25,1.5$ and $0.92 \%$, respectively. Sum of squares partitioning in most variables showing statistically significant treatment effects (hen body weight, egg weight, yolk color) indicated little effect attributable to oat variety (Gwen, Paul, Streaker) relative to diet formulation (Control, Oat + corn, Oat + wheat, Oat + wheat + corn). Higher ratios of oat variety to diet effect were observed for shell thickness, egg production, Haugh Units and blood spots, but treatment effects for these variables were not statistically significant and observed patterns may have been random (Table 5). Only in the case of meat spots were we able to both identify a statistically significant diet/oat effect and allocate a higher proportion of variance to oat variety than diet. Even in this case, however, pairwise contrasts showed no consistent patterns (Table 6). Meat spots and blood spots can be caused by stress rather than dietary factors (Campo and García Gil, 1998), raising the possibility that observed effects may have had to do with spatial variation in the barn not accounted for by the randomization of cage allocation.

In the economic analysis, diets with Gwen oats were costlier (Table 8) because a greater quantity of soybean meal was incorporated to compensate both for lower protein content of that ingredient and for lower protein in the oat grain (Table 3). However, calculated nutrient concentrations (Table 1) suggested that formulations actually over compensated and resulted in elevated feed conversion efficiencies for Gwen diets (Table 8), balancing economic performance.

We conclude that differences of grain nutritional concentrations at the magnitude of those observed between oat varieties included in the present study do not appear to give rise to differences in feed performance at a scale that would be detectable or relevant in commercial poultry operations. In the absence of variety-related physiological effects, producers should be guided by agronomic characteristics in variety selection, as higher yields will reduce the cost of hulless oat grain. At the same time, however, hulless oat varieties exist which show nutritional concentrations beyond the range of those studied here (Macleod et al., 2008). Such varieties may be sufficiently different to give rise to more pronounced effects on feed performance, positive or negative.

\section{Conclusions}

The oat plant grows well in areas with milder, wetter climates than those optimal for production of wheat or feed corn. The replacement of corn or wheat in poultry diets in such areas provides poultry producers with a locally grown option, which may appeal to market demand for environmentally friendly food and may be cheaper than organic corn or wheat, both of which are expensive, in high demand and not always available from domestic sources. Data from the present study were not sufficiently robust to generate strong conclusions regarding the comparison between substituting wheat and substituting corn, but do provide strong support for the viability of replacing either grain with hulless oats in organic poultry diets, even when hulless oats are assumed to cost more than organic corn. The increased cost of oat containing diets relative to an oat-free control in the present study was offset by larger egg sizes in Hy-Line Brown hens between 24 and 32 weeks of age. Effect size associated with oat variety was generally much smaller than that associated with diet formulation, and too small to be of interest in a commercial context.

Acknowledgements. L. R. W. is funded by a graduate fellowship from the Seed Matters initiative. This work was funded by a grant from Wilcox Family Farms of Roy, WA. The funder had 
no involvement in the design, execution, analysis or interpretation of the study. The authors offer their grateful thanks to Todd Coffey for assistance with statistical method development, Heaven Le A. Roberts and Kaitlyn Vander Pas for their participation in egg data collection, and in particular to Kimberley Goertzen for her excellent care of the hens.

\section{REFERENCES}

Agricultural Marketing Service. 2016a. Egg Market News Report. US Department of Agriculture, Des Moines, IA and Atlanta, GA.

Agricultural Marketing Service 2016b. National Shell Egg Index Price Report. US Department of Agriculture, Des Moines, IA and Atlanta, GA.

Aguilar, J., Gramig, G.G., Hendrickson, J.R., Archer, D.W., Forcella, F., and Liebig, M.A. 2015. Crop species diversity changes in the United States: 1978-2012. PLoS ONE 10: $\mathrm{e} 0136580$.

AOAC 2005. Official Methods of Analysis. 18th ed. AOAC International, Gaithersburg, MD.

AOCS 2013. Official Methods and Recommended Practices of the AOCS. 6th ed. AOCS, Urbana, IL.

Batal, A., Dale, N., and Persia, M. 2011. Ingredient Analysis Table. 2012 ed. Feedstuffs, Bloomington, MN.

Bjerga, A. 2015. U.S. Forced to Import Corn as Shoppers Demand Organic Food. Bloomberg News. Available at Web site http://www.bloomberg.com/news/articles/2015-0415/romanian-corn-imports-to-u-s-surge-as-shoppers-demandorganic (verified 28 June 2016).

Bretz, F., Hothorn, T., and Westfall, P.H. 2011. Multiple Comparisons Using R. CRC Press, Boca Raton, FL.

Brindzová, L., Čertík, M., Rapta, P., Zalibera, M., Mikulajová, A., and Takácsová, M. 2008. Antioxidant activity, beta-glucan and lipid contents of oat varieties. Czech Journal of Food Science 26(3):163-173.

Brouwer, J. and Flood, R.G. 1995. Aspects of oat physiology. In Welch, R.W. (ed.). The Oat Crop: Production and Utilization. World Crop Series. Chapman \& Hall, London. p. 177-222.

Burrows, V.D., Cave, N.A., Hamilton, R.M.G., and Morris, J.M. 1993. Production and Feeding of nAked Oat. Agriculture Canada, Ontario, CA.

Campo, J.L. and García Gil, M. 1998. Internal inclusions in brown eggs: Relationships with fearfulness and stress. Poultry Science 77(12):1743-1747.

Cave, N.A., Hamilton, R.M.G., and Burrows, V.D. 1989. Evaluation of naked oats (Avena nuda) as a feedstuff for laying hens. Canadian Journal of Animal Science 69(3): 789-799.

Dewey, H. 2016. National Organic Grain and FeedstuffsMonthly/Quarterly. US Department of Agriculture, Agricultural Marketing Service, Greeley, Colorado.

Economic Research Service. 2014. Wholesale Prices for Organic Grains and Feedstuffs, U.S., Monthly, 2011-13. US Department of Agriculture, Washington, DC.

Economic Research Service. 2016. Wheat Yearbook Table 1. Planted Acreage, Harvested Acreage, Production, Yield, and Farzm Price. US Department of Agriculture, Washington, DC.

Eisen, E.J., Bohren, B.B., and McKean, H.E. 1962. The Haugh Unit as a measure of egg albumen quality. Poultry Science 41:1461-1468.
Eleveld, B., Silberstein, T., Mellbye, M., Flowers, M., and Lahmann, E. 2010. Enterprise Budget: Spring Oats, Willamette Valley Region. Oregon State University Extension Service, Corvallis, Oregon.

Fernandez-Cornejo, J., Wechsler, S.J., Livingston, M., and Mitchell, L. 2014. Genetically Engineered Crops in the United States. US Department of Agriculture, Economic Research Service, Washington, DC.

Greene, C., Wechsler, S.J., Adalja, A., and Hanson, J. 2016. Economic Issues in the Coexistence of Organic, Genetically Engineered (GE), and Non-GE crops. US Department of Agriculture, Economic Research Service, Washington, DC.

Global Agricultural Trade System. 2016. Imports: Organic Yellow Dent Corn, Jan 2011 - Dec 2016. US Department of Agriculture, Foreign Agricultural Service. Available at Web site http://apps.fas.usda.gov/gats/ExpressQuery1.aspx (verified 5 March 2017).

Heneghan, C. 2015. The Non-GMO Industry is Growing Fast. Where Does it Go From Here? Food Dive. Available at Web site http://www.fooddive.com/news/the-non-gmo-industryis-growing-fast-where-does-it-go-from-here/404409/ (verified 28 June 2016).

Hernández, J.M., Beardsworth, P.M., and Weber, G. 2005. Egg quality-meeting consumer expectations. International Poultry Production 13(3):20-23.

Hernández, J.M. and Blanch, A. 2006. Perceptions of egg quality in Europe. Proceedings of the Australian Poultry Science Symposium 18:261-268.

Hothorn, T., Bretz, F., Westfall, P., Heiberger, R.M., Schuetzenmeister, A., and Scheibe, S. 2008. Simultaneous Inference in General Parametric Models. Biometrical Journal 50(3):346-363.

Hsun, C.L. and Maurice, D.V. 1992. Nutritional value of naked oats (Avena nuda) in laying hen diets. British Poultry Science 33(2):355-361.

Hy-Line International. 2016. Hy-Line Brown Commercial Layers Management Guide. Available at Web site http://www.hyline. com/UserDocs/Pages/BRN_COM_ENG.pdf (verified 27 June 2016).

Józefiak, D., Rutkowski, A., Jensen, B.B., and Engberg, R.M. 2006. The effect of $\beta$-glucanase supplementation of barleyand oat-based diets on growth performance and fermentation in broiler chicken gastrointestinal tract. British Poultry Science 47(1):57-64.

Laux, M. 2012. Pastured Poultry Profile. Agriculture Marketing Resource Center. Available at Web site http://www.agmrc. org/commodities-products/livestock/poultry/pastured-poultryprofile/ (verified 28 June 2016).

Liebman, M., Helmers, M.J., Schulte, L.A., and Chase, C.A. 2013. Using biodiversity to link agricultural productivity with environmental quality: Results from three field experiments in Iowa. Renewable Agriculture and Food Systems 28(2):115-128.

Macleod, M. 2004. Performance and Egg Quality in Laying Hens Fed on Naked Oats. Department for Environment, Food and Rural Affairs, London, UK.

Macleod, M., Nute, G., and Wade, A. 2004. Avian Feed Efficiency From Naked Oats. Department for Environment, Food and Rural Affairs, London, UK.

Macleod, M.G., Valentine, J., Cowan, A., Wade, A., McNeill, L., and Bernard, K. 2008. Naked oats: Metabolisable energy yield from a range of varieties in broilers, cockerels and turkeys. British Poultry Science 49(3):368-377. 
Marusich, W.L. and Bauernfeind, J.C. 2012. Oxycarotenoids in poultry feed. In Bauernfeind, J.C. (ed.). Carotenoids as Colorants and Vitamin A Precursors: Technological and Nutritional Applications. Academic Press, Inc., New York. p. 319-462.

Maurice, D.V., Jones, J.E., Hall, M.A., Castaldo, D.J., Whisenhunt, J.E., and McConnell, J.C. 1985. Chemical composition and nutritive value of naked oats (Avena nuda L.) in broiler diets. Poultry Science 64(3):529-535.

McNab, J.M. and Smithard, R.R. 1992. Barley $\beta$-Glucan: An Antinutritional Factor in Poultry Feeding. Nutritional Research Reviews 5(1):45.

National Agricultural Statistics Service 2014. 2012 Census of Agriculture. US Department of Agriculture, Washington, DC.

National Agricultural Statistics Service 2015. 2014 Organic Survey. US Department of Agriculture, Washington, DC.

National Agricultural Statistics Service 2016a. Prices Received for Corn by Month-United States. US Department of Agriculture, Washington, DC.

National Agricultural Statistics Service 2016b. Oats 2015: Production by County for Selected States. US Department of Agriculture, Washington, DC.

Pinheiro, J., Bates, D., DebRoy, S., Sarkar, D., and R Development Core Team. 2016. nlme: Linear and Nonlinear Mixed Effects Models. R package version 3.1-128. Available at Web site http://CRAN.R-project.org/package= nlme (verified 17 October 2016).
R Development Core Team. 2008. R: A Language and Environment for Statistical Computing. R Foundation for Statistical Computing, Vienna, Austria.

Sandeski, L.M., Ponsano, E.H.G., and Neto, M.G. 2014. Optimizing xanthophyll concentrations in diets to obtain well-pigmented yolks. Journal of Applied Poultry Research 23(3):409-417.

Shaw, R.H. 1988. Climate Requirement. Agronomy Monograph, Corn and Corn Improvement 18:609-638.

Spada, F.P., Selani, M.M., Coelho, A.A.D., Savino, V.J.M., Rodella, A.A., Souza, M.C., Fischer, F.S., Lemes, D.E.A., and Canniatti-Brazaca, S.G. 2016. Influence of natural and synthetic carotenoids on the color of egg yolk. Scientia Agricola 73(3):234-242.

Valentine, J. 1995. Naked oats. In Welch, R.W. (ed.). The Oat Crop: Production and Utilization. Chapman \& Hall, London, UK. p. 504-532.

Washington State Legislature. 2016. Washington Administrative Code, Title 16, Chapter 16-104, Section 16-104-220.

Webster, F.H. 2011. Oat utilization: Past, present, and future. In Webster, F.H. and Wood, P.J. (eds). Oats: Chemistry and Technology. Grain Science References. AACC International, Inc., Saint Paul, MN. p. 347-361.

Welch, R.W., Peterson, D., and Schramka, B. 1988. Hypocholesterolemic and gastrointestinal effects of oat bran fractions in chicks. Nutrition Reports International 38:551-561. 